those from Maine, while those from Pullman present almost the two extremes of elytral punctation and clearly demonstrate that no line can be drawn by the sculpture. In both series specimens vary from almost entirely testaceous, (having an occipital spot and the suture darker, and the abdomen and metasternum black) to entirely black, with the antennæ, mouth parts, and tarsi piceous. The California specimens all measure $5 \mathrm{~mm}$. in length while the Pullman specimens vary from 4 to $7 \mathrm{~mm}$.

In all the series examined the darker specimens have a closer and deeper punctation but the series from Ahwahnee present such an extreme that, if it were not for intermediates like those from Pullman, they would appear to merit specific rank.

\title{
THE HOUSE FLY IN ITS RELATION TO CITY GARBAGE. ${ }^{1}$
}

\section{By John Howard Paine.}

In connection with an endeavor to introduce into the city of Boston the use of paper bags in garbage pails, with the idea of preventing fly maggots from remaining attached to the sides of the pails after collection of the contents, the question arose, "Does the housefly breed extensively in garbage?" To obtain data upon this subject, experiments were undertaken to breed out flies from miscellaneous collections of maggots occurring in city garbage.

Considerable attention has been given to the breeding places of the house fly. A general idea seems to prevail that this species seldom develops in garbage. Howard ${ }^{2}$ quotes Professor J. S. Hine, of Ohio State University, as being of the opinion that "while house flies visit garbage in numbers, they appear in most cases to be after food only, as only a few specimens of this species were reared from such material during the season when he was at work." Howard then goes on to say that Professor Hine found that the fly which commonly bred in fermenting vegetable refuse from the kitchen was not the typhoid fly, but Muscina stabulans,

\footnotetext{
${ }^{1}$ Contributions from the Entomological Laboratory of the Bussey Institution, Harvard University, No. 58.

${ }^{2}$ Howard, L. O. The House Fly-Disease Carrier. F. A. Stokes Co., New York (1911) p. 9 .
} 
the so-called stable fly. To quote further, "Musca domestica was also reared, as was also another species known as Phormia regina, but it seems from these observations, although they were limited to a single locality in Central Ohio, that the recently acquired opinion to the effect that the typhoid fly breeds abundantly in vegetable refuse when it has reached the proper fermenting stage is due many times to the mistake of considering the stable fly and its larvæ as those of $M$. domestica." As will be seen by reference to the table given below, but a single occurrence of Muscina stabulans was recorded in the present experiments.

Newstead carefully investigated the breeding places of these flies in the city of Liverpool and his results, as given by Howard, tend to confirm those of the present writer. He found that the housefly bred in ash pits containing vegetable refuse in the proper state of fermentation, often to the same extent as in stable manure.

Professor R. W. Doane ${ }^{1}$ states that, "Decaying vegetables or fruit, fermenting kitchen refuse and other materials sometimes also serve as breeding places." Smith ${ }^{2}$, in his observations on the breeding of flies in human excrement in India, has discovered many of these insects issuing from this source, as has previously been noted by others.

The conditions in the section visited in the present instance, one of Boston's tenement districts, would appear to one unaccustomed to such sights, quite alarming. Various species of Muscids, including a large percentage of houseflies, we found swarming about the garbage, depositing eggs and feeding upon it and upon other refuse thrown into the alleys. These were the flies that were supplying the nearby restaurants in such numbers.

The larvæ were collected from the conțents of various pails as they were emptied into the carrier's wagon. As a rule they were found in quantities and often were so abundant that the interior of the receptacle appeared as a wriggling mass. In the laboratory the maggots were placed in covered boxes containing a little earth in which they could pupate, and were fed upon stale, water-soaked bread. In a few lots kept in milk bottles the mature larvæ crawled

\footnotetext{
1 Doane, R. W. Insects and Disease. American Nature Ser., Group IV, Henry Holt \& Co. New York (1910) p. 63.

${ }^{2}$ Smith, F. A Further Note on the Ways of Common Flies in India. Jour. Royal Army Medical Corps. (July, 1908).
} 
up the sides and into the loose muslin cover in order to find a dry place to pupate. No doubt they escape from the garbage receptacles in the same manner. Cracks or openings in the bottom of receptacles afford an easy means of exit, and often when a garbage barrel was moved many maggots were found on the ground underneath. The little garbage "houses" in which the cans are often kept are excellent places for the larvæ, the floor always containing many cracks by means of which they may easily obtain access to the dry ground underneath. In instances where the garbage had not been collected for two or three weeks, an all too common occurrence, many larvæ had pupated in the dryer, fresher material which had recently been thrown in.

TABLE OF REARINGS SHOWING NUMBER AND PROPORTION OF EACH SPECIES COLLECTED.

\begin{tabular}{|c|c|c|c|c|c|c|c|}
\hline \multirow[b]{2}{*}{ Lot No. } & \multicolumn{5}{|c|}{ Number of specimens. } & \multirow[b]{2}{*}{$\begin{array}{c}\text { Percentage } \\
\text { of house } \\
\text { flies. }\end{array}$} & \multirow[b]{2}{*}{$\begin{array}{l}\text { Date of } \\
\text { collection }\end{array}$} \\
\hline & $\begin{array}{c}\text { Musca } \\
\text { domes- } \\
\text { tica. }\end{array}$ & $\begin{array}{l}\text { Phor- } \\
\text { mia } \\
\text { regina. }\end{array}$ & $\begin{array}{l}\text { Lucilia } \\
\text { seri- } \\
\text { cata. }\end{array}$ & $\begin{array}{c}\text { Calli- } \\
\text { phora } \\
\text { erythro- } \\
\text { cephala. }\end{array}$ & $\begin{array}{c}\text { Muscina } \\
\text { stabu- } \\
\text { lans. }\end{array}$ & & \\
\hline I & 80 & & 40 & & & 66.6 & Sept. 5 \\
\hline II & 9 & & 1 & & & 90. & $"$ \\
\hline III & 1 & & 7 & & & 12.5 & “ \\
\hline IV & 8 & 5 & 60 & & & 10.9 & “ \\
\hline V & 4 & & 16 & & 1 & 19. & “ \\
\hline VI & & & 3 & & & 0. & Sept. 9 \\
\hline VII & 26 & & 1 & & & 96.3 & “ \\
\hline VIII & 7 & & & & & 100. & “ \\
\hline IX & 1 & 1 & 100 & 27 & & .78 & Aug. 10 \\
\hline $\mathbf{X}$ & & 139 & 110 & 2 & & 0. & \\
\hline Totals . & 136 & 145 & 338 & 29 & 1 & & \\
\hline Per cent. . & 22.4 & 22.3 & 50.5 & 4.4 & .1 & 22.4 & \\
\hline
\end{tabular}

When one considers the great numbers of Muscids issuing from the garbage every day during the warm summer months, the presence of twenty-two percent of house flies means that this place of breeding ranks among the first to be considered in a cam- 
paign against this insect. The writer has not studied the conditions in other cities but would venture the opinion that those which obtain here are in no way peculiar to this locality.

\section{NOTE ON A PINK LOCUSTID.}

While at Woods Hole, Mass., in August, Dr. A. S. Pearse gave me a pink male Locustid which he found on some blackberry bushes in the vicinity. At the time I received the insect, it had not passed through its last instar and I was very much interested to see whether or not it would retain its beautiful pink color after passing through this final stage. Professor Morgan was interested in the animal, and according to his advice, I constructed a cage over some blackberry bushes in a field, thinking that conditions which were approximately the same as natural conditions might be the most favorable for development.

The insect passed through its last moult about one week after I had it in my possession and is fully as pink, wings included, as before, with the exception of the eyes which are white and the ventral side of the thorax and abdomen which are considerably lighter than the other regions of the body.

At present we are engaged in attempting to cross this Locustid with normal green ones of the same species in order to find out what the mendelizing characters are.

Mr. Gray, the curator, found a similar pink form early this summer and, according to Professor Morgan, a yellow form was taken several years ago. This led Professor Morgan to make the suggestion that two factors may be involved, the presence of both of which produces the pink form, the absence of one the yellow and the absence of both factors the ordinary normal green form.

R. W. Glaser. 

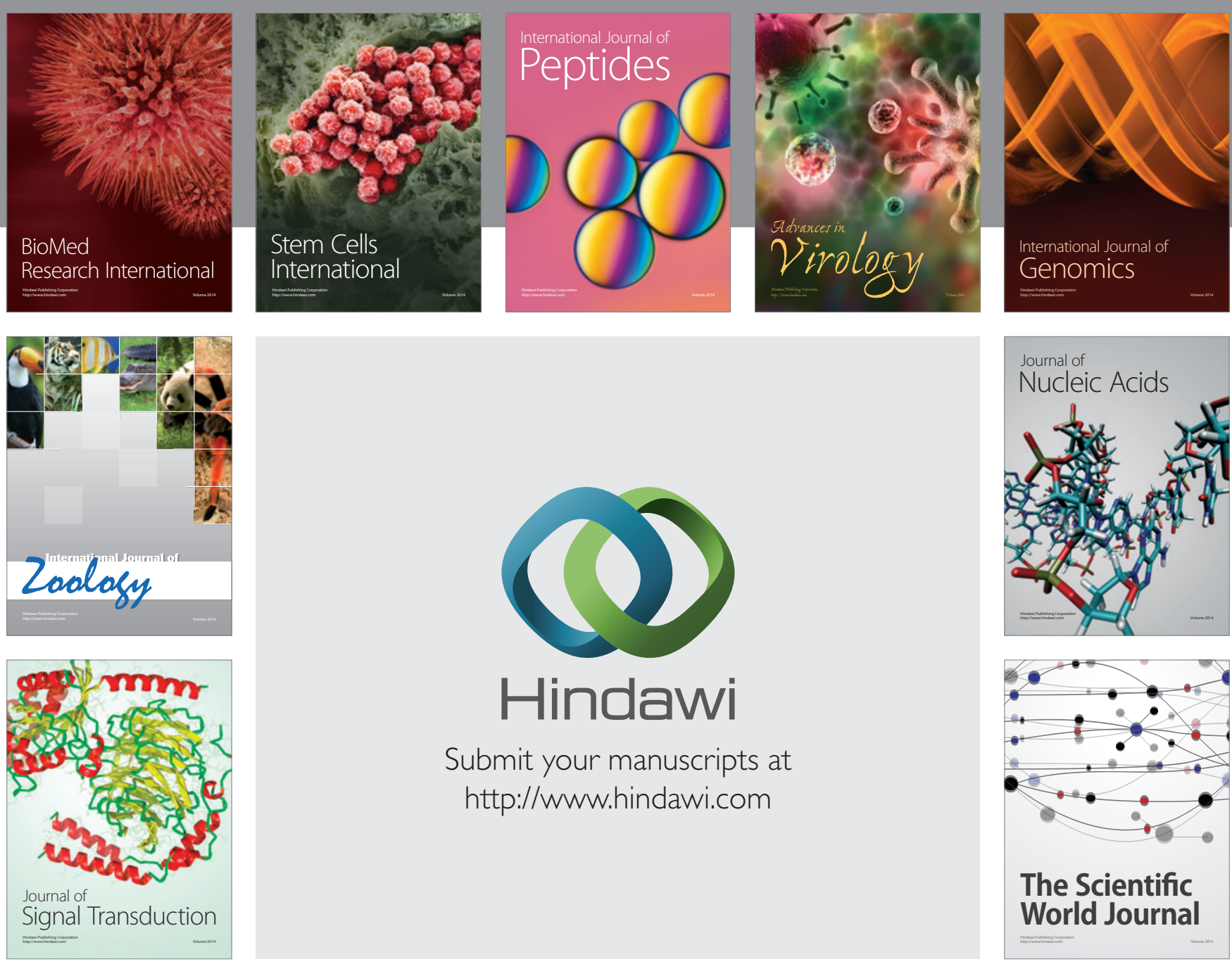

Submit your manuscripts at

http://www.hindawi.com
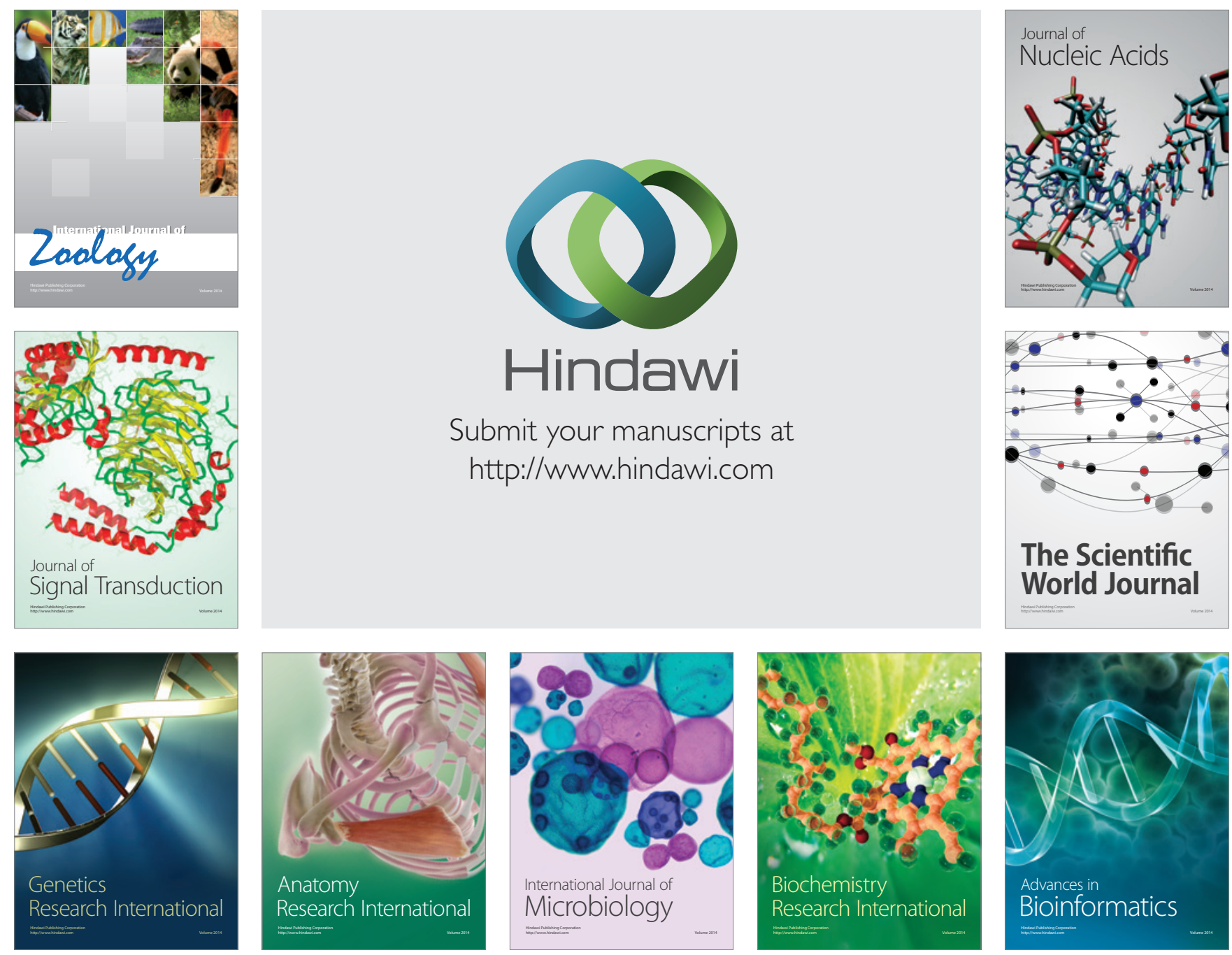

The Scientific World Journal
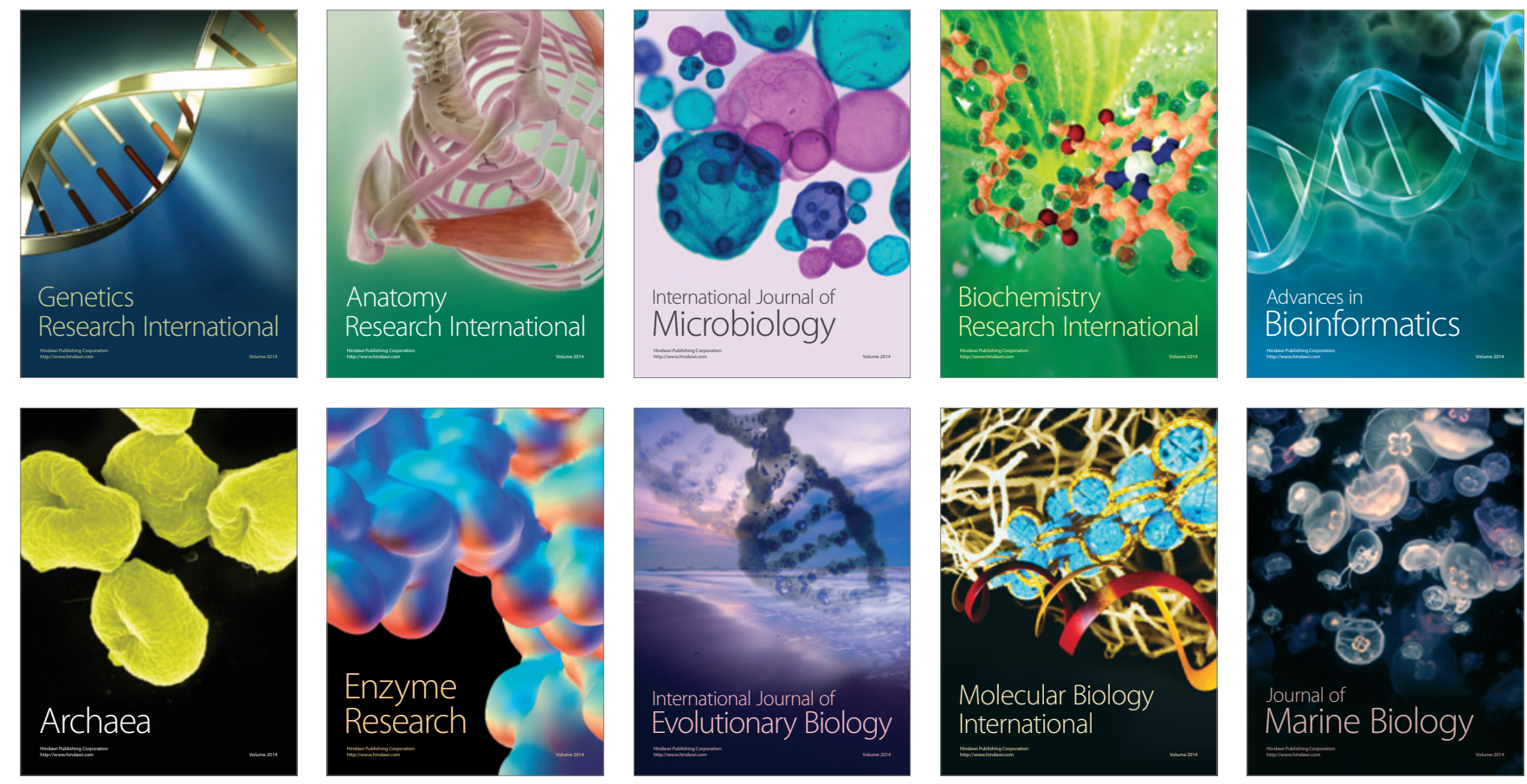